\title{
Postnatal maternal attachment: a retrospective study
}

\author{
Derya Yüksel Koçak', Handan Özcan² \\ ${ }^{1}$ Department of Nursing, Vocational School of Health Services, Hitit University, Çorum, Turkey \\ ${ }^{2}$ Department of Nursing, Faculty of Health Sciences, Gümiïshane University, Gümiisshane, Turkey
}

\begin{abstract}
Objective: In this study, we aimed to determine the level of postnatal maternal attachment and the factors affecting the attachment.

Methods: A total of 300 women (of which 150 delivered vaginally and 150 delivered by cesarean section) who applied to family health centers in Gümüşhane city, delivered a live fetus at term vaginally or by cesarean section, did not develop any maternal or fetal health problem and complication during postpartum period, and had 0-60-month-old baby between April 20 and July 20, 2017 were included in this descriptive and cross-sectional study.

Results: In the study, no significant correlation was found among the factors such as women's educational status, employment status, perceiving income status, family type, history of risky pregnancy, gravida, delivery week, delivery type, delivery duration, age of baby, having problem during pregnancy and delivery, postpartum depression, having support during delivery, the type of feeding baby, and attending pregnancy training classes. It was determined that the variables such as marital status, place of residence, marriage duration, number of delivery and child, whether the pregnancy is planned or not, first breastfeeding time after delivery affected the maternal attachment level of women. It was found that women whose age was between 27 and 35 years, who were housewife or civil servant, residing in a city, married for maximum 10 years, had single child and planned their pregnancies had higher maternal attachment levels.

Conclusion: In order to increase maternal attachment, women need to plan their pregnancies willingly, and families should be observed for attachment and supported for a safe attachment.
\end{abstract}

Keywords: Mother, delivery type, maternal attachment, postpartum.

\section{Özet: Postnatal maternal bağlanma: Retrospekstif bir çalışma}

Amaç: Bu çalışmada postnatal dönemde maternal bağlanma düzeyini ve bağlanmayı etkileyen faktörleri belirlemeyi amaçladık.

Yöntem: Tanımlayıcı ve kesitsel türdeki çalışmaya 20 Nisan - 20 Temmuz 2017 tarihleri arasında, Gümüşhane ilinde aile sağlığı merkezlerine başvuran, termde, canlı bir fetüsü vajinal ya da sezaryen yolla doğuran, doğum sonrası dönemde maternal ve fetal sağlık sorunu ve komplikasyonu gelişmeyen, araştırmanın yapıldığ tarihler arasında 0-60 ay aralığında bebeği olan 150 vajinal, 150 sezaryen yolla doğum yapan toplam 300 kadın dahil edildi.

Bulgular: Çalışmada kadınların eğitim durumu, çalışma durumu, gelir durumunu algılama, aile tipi, riskli gebelik geçirme, gebelik sayısı, doğum haftası, doğum şekli, doğum süresi, bebeğin yaşı, gebelikte ve doğumda sorun yaşama, doğum sonrası depresyon, doğum sırasında destek alma, bebeği besleme şekli, gebe eğitim sınıflarına katılma gibi faktörler arasında anlamlı ilişki belirlenmedi. Medeni durum, meslek, yaşanılan yer, evlilik süresi, doğum sayısı ve çocuk sayısı, gebeliği isteme durumu ve doğum sonrası bebeği ilk emzirme zamanı değişkenlerinin kadınların maternal bağlanma düzeyini etkilediği belirlendi. 27-35 yaş arası, ev hanımı ya da memur olan, ilde ikamet eden, en fazla on yıldır evli olan, tek çocuğu olan ve gebeliği planlayan kadınların maternal bağlanma düzeylerinin daha yüksek olduğu saptandı.

Sonuç: Maternal bağlanmanın artırılması için özellikle kadınların gebeliklerini isteyerek planlamaları, bağlanma konusunda ailelerin gözlenmeleri ve güvenli bağlanma için desteklenmeleri gerekmektedir.

Anahtar sözcükler: Anne, doğum şekli, maternal bağlanma, doğum sonrası.
Correspondence: Derya Yüksel Koçak, MD. Department of Nursing, Vocational School of Health Services, Hitit University, Çorum, Turkey. e-mail: deryayuksel.guvenc@gmail.com Received: April 19, 2018; Accepted: July 26, 2018

Please cite this article as: Koçak DY, Özcan H. Postnatal maternal attachment: a retrospective study. Perinatal Journal 2018;26(2):78-86.
Available online at: www.perinataljournal.com/20180262005 doi:10.2399/prn.18.0262005 QR (Quick Response) Code: 


\section{Introduction}

Kesebir et al. define the attachment as the child feeling an affinity to the caregiver in the relationship between them and as an emotional bond with consistency and continuity which becomes clear especially under stress. ${ }^{[1,2]}$ The attachment theory developed by Bowlby is based on the attachment of baby to mother during the early period as a result of biological trust, mother being available or not when baby needs her, and how reactions and behaviors of mother towards baby are perceived and interpreted by baby. ${ }^{[3]}$ Maternal attachment begins during pregnancy, continues after delivery and contributes to the development of maternity role in woman. ${ }^{[4,5]}$ In the attachment theory, it is highlighted that being attached to mother or any other relaxing object has a significant role for baby to maintain the life. ${ }^{[6]}$ When the bond between mother and baby is strong and based on love, it contributes to the development of child as a healthy individual socially, physically and mentally. ${ }^{[7,8]}$ When attachment, with foundations laid during infancy period, is determined once whether it is safe or not, it varies very slightly in the other periods of life. ${ }^{[1]}$ The level of attachment does not only ensure to have a healthy infancy period but also affects the health level during early childhood, late childhood, adolescence and adulthood periods. Bowlby stated that there is a link between insecure attachment and psychopathology ${ }^{[3]}$ It is indicated that insufficient attachment is associated with propensity for violence, selfharm, substance abuse and drug addiction, negligence and abuse..$^{[9]}$

During postpartum period, mother is very willing to establish intimacy with her baby. Mother seeing, touching and communicating with baby affects the perception of baby positively. If this positive communication cannot be established between mother and baby, mother may neglect the care of baby, and the health of mother and baby may deteriorate. Meeting with baby right after the delivery in order to initiate the interaction between mother and baby is very important in terms of establishing maternal attachment rapidly.$^{[10]}$ Factors such as protecting baby from harmful and dangerous situations, breastfeeding, caring and healthy attachment are effective in creating a positive environment for the healthy development of baby during postpartum period. ${ }^{[1]]}$ It has been stated that early attachment and breastfeeding improve the mathemati- cal and reading skills of children. ${ }^{[12]}$ While breast-fed babies are more compatible and cooperative, crying jags and anger are encountered less. ${ }^{[8]}$ According to the World Health Organization, depression seen in women disrupts the performance of fulfilling maternity roles, and also negatively affects the development and growth of baby. ${ }^{[13]}$

Mothers may have knowledge deficiency or insufficient social supports about baby care during postpartum period. During this period, nurses should support and encourage parenting efforts of mothers and fathers. ${ }^{[11]}$ Nurses should assess the relationship of mother and baby during postpartum period by observation and record it. For example, mother calming baby, caressing it, holding it, talking to baby, feeding properly, breastfeeding baby, mother feeling comfortable when breastfeeding, making an eye contact and calling baby with its name or gender are the appropriate attachment behaviors expected from mothers. Also, during postpartum period, putting baby naked on prone position onto the naked breasts of mother (namely, direct skin contact) stimulates maternal oxytocin release and affects maternal attachment positively. For the healthy assessment of the approach of mothers for their babies, nurses play a significant role in the normal attachment process between mother and baby and in the development positive mother-baby attachment after delivery. Performing proper midwifery and nursing initiatives are significant for maintaining maternal and fetal health, and identifying risks early that may develop in the attachment relationship between mother and baby. ${ }^{[10]}$

The purpose of this study is to determine the level of postnatal maternal attachment and the factors affecting the attachment.

\section{Methods}

\section{The population and sample of the study}

The population of this descriptive and cross-sectional study consisted of women living in a city of Eastern Black Sea region. The sample of the study consisted of women who delivered a live fetus at term vaginally or by cesarean section, did not develop any maternal or fetal health problem or complication at postpartum period and had a $0-60$-month-old baby during the study period. A total of 300 mothers, of which 150 
delivered vaginally and 150 delivered by cesarean section, who were informed about the purpose of the study and voluntarily accepted to participate, were the sample of this study. The data of the study were collected between April 20 and July 20, 2017. Women who were the sample of the study were reached from the family health centers in Gümüşhane city.

\section{Data collection tools}

For the collection of study data, the information form developed according to the literature and maternal attachment scale were used.

Participant Information Form: The information form has 34 questions for demographic characteristics and details about delivery and postpartum period of woman. This form includes questions for demographic characteristics such as participant's age, current marital status, educational level and spouse's educational level, income information, marriage duration and family type as well as information such as pregnancy, miscarriage and delivery numbers, problems during pregnancy, delivery type, delivery duration, planning status of pregnancy, preparing for motherhood during pregnancy and breastfeeding time during postpartum period, having postpartum depression, feeding type, and social support perception during and after delivery.

Maternal Attachment Scale: The scale which evaluates the emotions and behaviors showing maternal love based on the self-statements of individual was developed by Mary E. Müller in 1994. ${ }^{[5]}$ The fourpoint Likert scale has a total of 26 items. Total score is obtained by adding all points given to scale items $(\min =26, \max =104$. The increase of the scale shows that maternal attachment has a good level. Cronbach's alpha internal consistency reliability of the scale was 0.77 for mothers with 1 -month-old baby and 0.82 for mothers with 4-month-old baby. ${ }^{[14]}$ In our study, Cronbach's alpha internal consistency coefficient was 0.874 .

\section{Ethical aspect and practice of the study}

The approval of Ethics Committee of Gümüşhane University was obtained to collect study data. The participants were informed that their personal information would be kept confidential and would be used only for the purposes of this study. Then, the mothers who agreed to participate and gave verbal consent were included in the sample of the study. After data collection forms were delivered, the participants were asked to complete the forms. The participants completed the data collection forms within 15-20 minutes.

\section{The Analysis and Interpretation of the Data}

The study data were analyzed in the SPSS 18.0 package program. Number and percentage distribution was used for the analysis of the data, and mean-standard deviation was used for continuous data. Since the data did not have normal distribution, Kruskal-Wallis $\mathrm{H}$ test, ANOVA, $t$ test and Mann-Whitney $U$ test were used to compare the mean values of two or more groups in the independent groups. The value $\mathrm{p}<0.05$ was considered statistically significant.

\section{The Limitations of the Study}

The results obtained from this study are limited with the sample of this study. The results cannot be generalized to all mothers. Since the educational levels of women are different, it was observed that they had difficulties to complete the forms and they did not answer all questions in some forms. Also, as the questions are retrospective, some mothers had difficulties to remember some details, which was the greatest limitation of the study. Sample group being small, data being based on self-statement and the study being cross-sectional are other limitations.

\section{Results}

Some demographic characteristics of the participants are given in Table 1.

It was found that the ages of approximately half of the women $(48.7 \%)$ were in the range of $27-35$ (min: 19, max: 56, mean: $30.33 \pm 6.373$ ) years, most of them $(97.3 \%)$ were married, 3 out of every 10 women $(34.7 \%)$ were high school graduate, approximately 7 out of every 10 women $(68 \%)$ were housewife and did not work $(68.3 \%)$ at the time of study. More than half of them (53\%) were living in the city center, and 7 out of every 10 women $(68.3 \%)$ perceived that their incomes were equal to their expenses. Most of the women $(75.7 \%)$ had nuclear family, and the majority of them $(71.3 \%)$ were married for $1-10$ years.

Most of the women (69\%) in this study were multigravida and approximately half of them (49\%) had 2-3 children. A great majority of them (90\%) did not end 
their pregnancy by abortion previously, and most of them $(73.3 \%)$ did not have involuntary miscarriage. Almost all of them stated that they had no health problem in their previous pregnancy, and the most common problem in the previous pregnancy was infection $(\mathrm{n}=8, \% 57.1)$.

The details of the last pregnancies of the participants are given in Table 2.

Most of the women (79\%) included in the study planned their last pregnancies, and one of every 4 women $(25 \%)$ had a risky pregnancy in their last pregnancies. The children of $67.3 \%$ of women were between 0 and 2 years old during the study period and 6 out every 10 women (59\%) delivered at term. Almost all of them $(97.3 \%)$ stated that their delivery took less

Table 1. Demographic characteristics of women.

\begin{tabular}{|c|c|c|}
\hline & $\mathbf{n}$ & $\%$ \\
\hline \multicolumn{3}{|l|}{ Age } \\
\hline 19-26 & 86 & 28.7 \\
\hline $27-35$ & 146 & 48.7 \\
\hline 36 and above & 68 & 22.7 \\
\hline \multicolumn{3}{|l|}{ Marital status } \\
\hline Married & 292 & 97.3 \\
\hline Single/Divorced & 8 & 2.7 \\
\hline \multicolumn{3}{|l|}{ Employment } \\
\hline Housewife/Retired & 204 & 68.0 \\
\hline Employed & 96 & 32.0 \\
\hline \multicolumn{3}{|l|}{ Residence } \\
\hline Village & 40 & 13.3 \\
\hline District & 104 & 34.7 \\
\hline City & 156 & 52.0 \\
\hline \multicolumn{3}{|l|}{ Marriage duration } \\
\hline $1-10$ years & 214 & 71.3 \\
\hline $11-20$ years & 73 & 24.3 \\
\hline 21 years and above & 13 & 4.3 \\
\hline \multicolumn{3}{|l|}{ Educational level } \\
\hline Primary school & 54 & 18.0 \\
\hline Secondary school & 69 & 23.0 \\
\hline High school & 104 & 34.7 \\
\hline University & 73 & 24.3 \\
\hline \multicolumn{3}{|l|}{ Employment status } \\
\hline Yes & 95 & 31.7 \\
\hline No & 205 & 68.3 \\
\hline \multicolumn{3}{|l|}{ Perceiving income status } \\
\hline Income is less than expenses & 56 & 18.7 \\
\hline Income is equal to expenses & 205 & 68.3 \\
\hline Income is higher than expenses & 39 & 13.0 \\
\hline \multicolumn{3}{|l|}{ Family type } \\
\hline Nuclear family & 227 & 75.7 \\
\hline Extended family & 67 & 22.3 \\
\hline Separated family & 6 & 2.0 \\
\hline
\end{tabular}

than 3 hours. A great majority of women $(81.3 \%)$ did not have postpartum depression. Of those who had postpartum depression, $42.9 \%$ stated that they received support mostly from their partners. Almost half of women $(49.3 \%)$ said that they breast-fed their babies within the first half hour after delivery and most

Table 2. The details of the last pregnancies of women.

\begin{tabular}{|c|c|c|}
\hline & $\mathbf{n}$ & $\%$ \\
\hline \multicolumn{3}{|c|}{ Voluntarily planning last pregnancy } \\
\hline Yes & 237 & 79.0 \\
\hline No & 63 & 21.0 \\
\hline \multicolumn{3}{|l|}{ Current age of baby } \\
\hline 0-24 months & 202 & 67.3 \\
\hline 25-36 months & 48 & 16.0 \\
\hline 37 months and above & 50 & 16.7 \\
\hline \multicolumn{3}{|c|}{ Having postpartum depression } \\
\hline Yes & 56 & 18.7 \\
\hline No & 244 & 81.3 \\
\hline \multicolumn{3}{|c|}{ Person supporting women who had postpartum depression } \\
\hline Spouse & 24 & 42.9 \\
\hline Parents & 8 & 14.3 \\
\hline Sibling & 3 & 5.4 \\
\hline Family & 9 & 16.1 \\
\hline Health professional & 2 & 3.6 \\
\hline No one & 10 & 17.9 \\
\hline \multicolumn{3}{|c|}{ The first time when baby was held after delivery } \\
\hline 0-day data & 28 & 9.3 \\
\hline $0-30 \mathrm{~min}$. & 11 & 3.7 \\
\hline $31-60 \mathrm{~min}$. & 210 & 70.0 \\
\hline 61 minutes and more & 51 & 17.0 \\
\hline \multicolumn{3}{|c|}{ Treatment status of those with postpartum depression } \\
\hline Yes & 14 & 25 \\
\hline No & 42 & 75 \\
\hline \multicolumn{3}{|c|}{ Risky pregnancy history in last pregnancy } \\
\hline Yes & 75 & 25.0 \\
\hline No & 225 & 75.0 \\
\hline \multicolumn{3}{|l|}{ Birth week of baby } \\
\hline 24-34 weeks & 3 & 1.0 \\
\hline 34-40 weeks & 177 & 59.0 \\
\hline 41 weeks and above & 120 & 40.0 \\
\hline \multicolumn{3}{|l|}{ Delivery duration } \\
\hline 3 hours and below & 292 & 97.3 \\
\hline More than 3 hours & 8 & 2.7 \\
\hline \multicolumn{3}{|c|}{ Person supporting women during delivery } \\
\hline Spouse & 94 & 31.3 \\
\hline Mother & 73 & 24.3 \\
\hline Sibling & 23 & 7.7 \\
\hline Family & 97 & 32.3 \\
\hline Health professional & 6 & 2.0 \\
\hline No one & 7 & 2.3 \\
\hline \multicolumn{3}{|c|}{ The first time when baby was breast-fed after delivery } \\
\hline No breastfeeding & 29 & 9.7 \\
\hline 0-30 min. & 148 & 49.3 \\
\hline $31-60 \mathrm{~min}$. & 72 & 24.0 \\
\hline 61 minutes and more & 51 & 17.0 \\
\hline
\end{tabular}


of them $(70 \%)$ said that they held their babies within the first hour. In their last deliveries, $31.3 \%$ of women said that they were accompanied by their partners, $24.3 \%$ of them were accompanied by their mothers and $32.3 \%$ of them were accompanied by someone else other than their mothers and sisters.

By the statistical analysis of the study, it was found that the factors such as women's educational status, employment status, perceiving income status, family type, history of risky pregnancy, gravida, delivery week, delivery type, delivery duration, age of baby, having problem during last pregnancy and delivery, postpartum depression, having support during delivery, the type of feeding baby, and attending pregnancy training classes did not have a statistically significant impact on women's maternal attachment scores.

The factors affecting the maternal attachment status of the participants are shown in Table 3. It was found that the mean scores women got from maternal attachment scale varied according to the age. Accordingly, the mean scores got from maternal attachment scale by women between 19 and 26 $(97.92 \pm 6.199)$ years old and between 27 and 25 years old were higher than those of women who were 36 $(97.03 \pm 5.395)$ years old and above $(\mathrm{p}=0.031)$.

It was determined that marital status of women was affecting the scores of maternal attachment scale. The mean scores got from maternal attachment scale by

Table 3. Factors affecting maternal attachment scores of women.

\begin{tabular}{|c|c|c|c|c|c|c|c|}
\hline & Number & Min & $\operatorname{Max}$ & Mean & Median & SD & Test value \\
\hline $\begin{array}{l}\text { Age } \\
19-26 \text { years old } \\
27-35 \text { years old } \\
36+\text { years old }\end{array}$ & $\begin{array}{c}86 \\
146 \\
68\end{array}$ & $\begin{array}{l}78 \\
72 \\
82\end{array}$ & $\begin{array}{l}104 \\
104 \\
104\end{array}$ & $\begin{array}{l}97.92 \\
98.41 \\
97.03\end{array}$ & $\begin{array}{c}100.00 \\
100.00 \\
97.50\end{array}$ & $\begin{array}{l}6.199 \\
6.520 \\
5.395\end{array}$ & $\begin{array}{c}\quad p=0.031 \\
\text { Kruskal-Wallis test } \\
\chi^{2}=6.948\end{array}$ \\
\hline $\begin{array}{l}\text { Marital status } \\
\text { Married } \\
\text { Single }\end{array}$ & $\begin{array}{c}292 \\
8\end{array}$ & $\begin{array}{l}72 \\
78 \\
\end{array}$ & $\begin{array}{l}104 \\
104 \\
\end{array}$ & $\begin{array}{l}98.10 \\
92.88\end{array}$ & $\begin{array}{c}100.00 \\
96.00\end{array}$ & $\begin{array}{l}6.041 \\
9.538 \\
\end{array}$ & $\begin{array}{c}p=0.018 \\
t=2.370 \\
t \text { test }\end{array}$ \\
\hline $\begin{array}{l}\text { Profession } \\
\text { Housewife } \\
\text { Civil servant } \\
\text { Worker } \\
\text { Craftsperson }\end{array}$ & $\begin{array}{c}204 \\
55 \\
30 \\
11\end{array}$ & $\begin{array}{l}72 \\
85 \\
74 \\
78\end{array}$ & $\begin{array}{l}104 \\
104 \\
104 \\
104\end{array}$ & $\begin{array}{l}98.27 \\
98.64 \\
96.30 \\
93.18\end{array}$ & $\begin{array}{l}100.00 \\
100.00 \\
96.50 \\
97.00\end{array}$ & $\begin{array}{l}6.157 \\
5.307 \\
6.407 \\
8.268\end{array}$ & $\begin{array}{c}p=0.025 \\
\text { Kruskal-Wallis test } \\
\chi^{2}=9.362\end{array}$ \\
\hline $\begin{array}{l}\text { Residence } \\
\text { Village } \\
\text { District } \\
\text { City }\end{array}$ & $\begin{array}{c}40 \\
104 \\
156 \\
\end{array}$ & $\begin{array}{l}72 \\
78 \\
74 \\
\end{array}$ & $\begin{array}{l}104 \\
104 \\
104 \\
\end{array}$ & $\begin{array}{l}98.28 \\
96.80 \\
98.65 \\
\end{array}$ & $\begin{array}{c}99.50 \\
98.00 \\
100.00 \\
\end{array}$ & $\begin{array}{l}6.485 \\
6.557 \\
5.782 \\
\end{array}$ & $\begin{array}{c}\mathrm{p}=0.050 \\
\text { Kruskal-Wallis test } \\
\chi^{2}=9.362\end{array}$ \\
\hline $\begin{array}{l}\text { Marriage duration } \\
1-10 \text { years } \\
11-20 \text { years } \\
21 \text { years and above }\end{array}$ & $\begin{array}{c}214 \\
73 \\
13\end{array}$ & $\begin{array}{l}72 \\
78 \\
85\end{array}$ & $\begin{array}{l}104 \\
104 \\
104\end{array}$ & $\begin{array}{l}98.64 \\
96.04 \\
97.54 \\
\end{array}$ & $\begin{array}{c}100.00 \\
96.00 \\
100.00\end{array}$ & $\begin{array}{l}6.093 \\
6.054 \\
6.790 \\
\end{array}$ & $\begin{array}{c}\quad p=0.000 \\
\text { Kruskal-Wallis test } \\
\chi^{2}=16.264\end{array}$ \\
\hline $\begin{array}{l}\text { Parite } \\
\text { Primiparous } \\
\text { Multiparous }\end{array}$ & $\begin{array}{c}93 \\
207\end{array}$ & $\begin{array}{l}78 \\
72 \\
\end{array}$ & $\begin{array}{l}104 \\
104\end{array}$ & $\begin{array}{l}98.70 \\
97.62\end{array}$ & $\begin{array}{c}101.0 \\
99.0\end{array}$ & $\begin{array}{l}6.377 \\
6.095\end{array}$ & $\begin{array}{c}\mathrm{p}=0.032 \\
\text { Mann-Whitney } U \text { test }\end{array}$ \\
\hline $\begin{array}{l}\text { Number of children } \\
1 \\
2-3 \\
4 \text { and more }\end{array}$ & $\begin{array}{c}122 \\
147 \\
31 \\
\end{array}$ & $\begin{array}{l}78 \\
72 \\
78 \\
\end{array}$ & $\begin{array}{l}104 \\
104 \\
104 \\
\end{array}$ & $\begin{array}{l}98.87 \\
97.31 \\
97.45\end{array}$ & $\begin{array}{l}101.00 \\
98.00 \\
99.00\end{array}$ & $\begin{array}{l}5.999 \\
6.191 \\
6.702\end{array}$ & $\begin{array}{c}\mathrm{p}=0.020 \\
\text { Kruskal-Wallis test } \\
\chi^{2}=7.833\end{array}$ \\
\hline $\begin{array}{l}\text { Willingly planned pregnancy } \\
\text { Yes } \\
\text { No }\end{array}$ & $\begin{array}{c}237 \\
63 \\
\end{array}$ & $\begin{array}{l}74 \\
72 \\
\end{array}$ & $\begin{array}{l}104 \\
104\end{array}$ & $\begin{array}{l}98.43 \\
96.19\end{array}$ & $\begin{array}{c}100.00 \\
97.00\end{array}$ & $\begin{array}{c}5.760 \\
7.39 \\
\end{array}$ & $\begin{array}{c}\mathrm{p}=0.030 \\
\text { Mann-Whitney U test }\end{array}$ \\
\hline $\begin{array}{l}\text { The first time when baby was bre } \\
\text { No breastfeeding } \\
\text { Within first half hour } \\
\text { Between half hour and one hour } \\
\text { After } 1 \text { hour }\end{array}$ & $\begin{array}{c}\text { delivery } \\
29 \\
148 \\
72 \\
51\end{array}$ & $\begin{array}{l}82 \\
72 \\
78 \\
74\end{array}$ & $\begin{array}{l}104 \\
104 \\
104 \\
104\end{array}$ & $\begin{array}{l}97.03 \\
97.82 \\
97.96 \\
98.86\end{array}$ & $\begin{array}{c}99.00 \\
98.50 \\
100.00 \\
101.00\end{array}$ & $\begin{array}{l}6.242 \\
5.658 \\
6.935 \\
6.615\end{array}$ & $\begin{array}{l}\text { ANOVA } \\
F=1.667 \\
p=0.023\end{array}$ \\
\hline
\end{tabular}


mothers who were single $(92.88 \pm 9.538)$ during the study period were lower than those of women who were married $(98.10 \pm 6.041)(\mathrm{p}=0.018)$.

While there is no statistically significant correlation between employment status and maternal attachment scale scores of women, the mean scores of maternal attachment scale varied according to the professions of women. The statistical analysis showed that maternal attachment scores of women who are housewife and civil servant were higher than those of women who are worker or craftsperson $(\mathrm{p}=0.025)$.

A statistically significant correlation was found between the place where women live and the scores of maternal attachment scale. Mean maternal attachment scores of women who continuously live in city were higher than those of women who live in districts or villages $(\mathrm{p}=0.050)$.

It was seen that the marriage duration of women was affecting their maternal attachment scores at a statistically significant level. The maternal attachment scores of women who are married for 11-20 years were lower $(\mathrm{p}=0.000)$.

It was found that the gravida of women was affecting their maternal attachment scores at a statistically significant level. Accordingly, there was statistically significant difference in terms of mean maternal attachment scores between primiparous women $(98.70 \pm 6.377)$ and multiparous women $(97.62 \pm 6.095)$ $(\mathrm{p}=0.032)$. The maternal attachment scores of primiparous women were higher. It was found in the study that the child number of women was affecting their mean maternal attachment scores at a statistically significant level. The mean maternal attachment scores of women who delivered their first child were higher than those of women who had more than one child $(\mathrm{p}=0.020)$.

There was a statistically significant correlation between planned pregnancy and mean maternal attachment scores of women ( $\mathrm{p}=0.030)$. Accordingly, the mean maternal attachment scores of women who planned their pregnancies were higher.

In our study, maternal attachment scores of women who breast-fed their babies after the first 30 minutes following the delivery were higher than those of women who did not breast-fed their babies or breastfed within 30 minutes after delivery $(\mathrm{p}=0.023)$. The factors associated with the maternal attachment scales are shown in Table 3.

In our study, there was a negative correlation between maternal attachment scores and marriage duration and numbers of pregnancy and delivery. As the marriage duration and numbers of pregnancy and delivery increased, maternal attachment scores decreased. Also, there was a positive correlation between maternal attachment scores and first breastfeeding time and the time when partner held the baby (Table 4).

\section{Discussion}

In our study, we found that the mean scores women got from maternal attachment scale varied according to the age. The maternal attachment levels of women who are 36 years old and above are the lowest. While there is no statistically significant correlation between the ages and maternal attachment scores of women in some studies, there are also some studies showing that maternal attachment scores of women increase as their age increases. ${ }^{[4,15-17]}$ In our study, we believe that the correlation between the increase of age and decrease of attachment is associated with the increases of marriage duration and the numbers of children and delivery.

We found that the mean maternal attachment scores of women who were single during the study period were lower. We think that this may be related with the fact that women who are married spend more and high quality time with their children as they share domestic roles and house and child-care responsibilities with their spouses.

In our study, we found that there is no statistically significant correlation between employment status and

Table 4. Factors associated with the scores of Maternal Attachment Scale.

\begin{tabular}{lcc} 
Associated factors & p value & $\begin{array}{c}\text { Spearmen's } \\
\text { correlation ( } r)\end{array}$ \\
Score - marriage duration & 0.003 & $-0.168^{*}$ \\
Score - number of children & 0.014 & $-0.142^{\dagger}$ \\
Score - parity & 0.009 & $-0.151^{*}$ \\
Score - the time when & 0.009 & $0.150^{*}$ \\
spouse holds baby & & $0.146^{\dagger}$ \\
Score - the first breastfeeding & 0.011 & \\
time after delivery & & \\
\hline
\end{tabular}

${ }^{*} p<0.01$ level of significance; ${ }^{\dagger} p<0.05$ level of significance. 
maternal attachment scores of women while maternal attachment scores of women who are housewife and civil servant are higher. Some studies reported that maternal attachment scores were higher in working women. ${ }^{[16,17]}$ In another study, there was no statistically significant correlation between employment status and maternal attachment scores. ${ }^{[4]}$ The increase of maternal attachment scores may be explained with the facts that civil servants who have higher incomes compared to other profession groups and women who are considered to prefer to be a housewife as they do not have any financial difficulties spare more time for and take care of their children personally.

We found that women who were residing in the city had higher mean maternal attachment scores. Considering that the city where we conducted the study is an agricultural zone, we believe that the women who live in the city are more vigorous physically and mentally than women who live in the districts and villages due to the reasons such as having less work load and not dealing with physically tiresome works like agricultural labors as well as house works. Therefore, the women who live in the city spare more time for their babies than the women who live in districts and villages, and this extra time contributes to an active attachment.

In our study, women who were married for less than 10 years and more than 21 years had higher maternal attachment scores. Durualp et al. found in their studies that women who are married for 21 years and more had higher maternal attachment scores. ${ }^{[17]}$ Unlike the results, Mutlu et al. found no significant correlation between the marriage duration and maternal attachment. ${ }^{[15]}$ As the age of mother increases, the duration of marriage increases and attachment decreases. The care responsibilities for a growing child of couples who are married more than 21 years decrease, and they spare more time with newborn. It is also believed that being a mother after a long time is a long-awaited feeling and it may increase the attachment.

In our study where we investigated the impact of gravida on maternal attachment, we found that maternal attachment level was higher in primiparous women than multiparous women. While there many studies with similar results, there are also studies showing that maternal attachment increases with the increase of child number. ${ }^{[15,16,18,19]}$ The authors highlighted that the less number of children is important in terms of the safety of attachment. ${ }^{[18]}$ This result of the study shows that maternal attachment is affected positively by the facts that women who are going to be a mother for the first time are inexperienced in terms of motherhood, they approach more sensitively to their children as they are inexperienced for taking care of a baby, they make more communication and share more with baby and they care about their responsibilities regarding baby care.

In our study, we found that women who willingly planned their last pregnancies had significantly higher maternal attachment scores. Similarly, Durualp et al. reported that women with planned pregnancy had higher maternal attachment scores. ${ }^{[17]}$ In some studies, no significant correlation was found between planned pregnancies and maternal attachment scores. ${ }^{[4,15]}$ It is considered that the factors such as woman being ready to be a mother, desiring to be pregnant, deciding to be a parent together with their spouses and woman adapting pregnancy more easily in planned pregnancies increase the level of healthy maternal attachment.

According to our data, there was no statistically significant correlation between the delivery type and maternal attachment scores of women. Work is available in studies that show similarity, as well as studies showing that attachment to vaginal deliveries is higher. ${ }^{[7,15-17]}$ We believe that this finding may be the result of the facts that data were collected retrospectively and women who did not have postpartum complication were analyzed.

In our study, we did not find any statistically significant correlation between the delivery week / week of gestation and maternal attachment scores of women. Similarly, Mutlu et al. did not find any statistically significant correlation between maternal attachment scores and term or preterm labor. ${ }^{[15]}$ Some studies reported that the maternal attachment was deteriorated after delivery as preterm babies were lacking physical contact, maternal intimacy and care during hospitalization. ${ }^{[2,21]}$ This finding in our study is a result of the facts that pregnant women gave birth at term and there was less number of babies that needed intense care.

We found no statistically significant correlation between postpartum depression and maternal attachment. Some studies reported that postpartum depression negatively affected maternal attachment levels of 
mothers. ${ }^{[1,22,23]}$ We think that our finding is caused by the fact that there are few women who were diagnosed with depression and on medication.

In our study, we found a negative correlation between maternal attachment scores and the increases of marriage duration and numbers of pregnancy and delivery of women. As the marriage duration and numbers of pregnancy and delivery increase, maternal attachment level decreases. There was also a positive correlation between the first breastfeeding time after delivery and maternal attachment score. The attachment increases as the breastfeeding time increases. Durualp et al. reported that women who held their babies within first 30 minutes after delivery and breastfed had higher maternal attachment levels. ${ }^{[17]}$ Attachment begins immediately with early breastfeeding and it contributes to the psychological, physical and mental development of children in their future lives. ${ }^{[8,12]}$

\section{Conclusion}

In this study, we retrospectively determined the factors affecting maternal attachment in women who delivered in the last five years. Women who are in young age group (27-35 years old), who are housewife or civil servant, live in the city, married for maximum ten years, have single child and planned their pregnancies have higher maternal attachment levels.

The attachment is an emotional bond between the baby and the parents. It starts at the period between second and third trimester of pregnancy and reaches up to postpartum and newborn periods. It contributes to physical, psychological and emotional development. Safe attachment is essential for a healthy generation. Therefore, women need to plan their pregnancies willingly, and families should be observed for attachment and supported for a safe attachment.

Conflicts of Interest: No conflicts declared.

\section{References}

1. Kesebir S, Kavzoğlu SÖ, Üstündağ MF. Bağlanma ve psikopatoloji. Psikiyatride Güncel Yaklaşımlar 2011;3:321-42.

2. Thompson RA. Attachment theory and research. In: Lewis, M. Child and adolescent psychiatry. 3rd ed. Philadelphia, PA: Lippincott Williams Wilkins; 2002. p. 164-72.
3. Elkin N. Gebelerin prenatal bağlanma düzeyleri ve bunları etkileyen faktörler. Sürekli Tıp Eğitim Degisi (Sted) 2015;24: 230-6.

4. Bilgin Z, Alpar ŞE. Kadınların maternal bağlanma algısı ve anneliğe ilişkin görüşleri. Sağlık Bilimleri ve Meslekleri Dergisi 2018;5:6-15.

5. Müller ME. Prenatal and postnatal attachment: a modest correlation. J Obstet Gynecol Neonatal Nurs 1996;25:161-6.

6. Yılmaz SD, Beji NK. Prenatal bağlanma envanteri'nin Türkçe'ye uyarlanması: güvenilirlik ve geçerlilik çalışması. Anadolu Hemşirelik ve Sağlık Bilimleri Dergisi 2013;16:1039.

7. Hergüner S, Çiçek E, Annagür A, Hergüner A, Örs R. Doğum şeklinin doğum sonrası depresyon, algılanan sosyal destek ve maternal bağlanma ile ilişkisi. Düşünen Adam 2014;27:15-20.

8. Gibbs BG, Forste R, Lybbert E. Breastfeeding, parenting, and infant attachment behaviors. Matern Child Health J 2018;22: 579-88.

9. Soysal AŞ, Bodur Ş, İşeri E, Şenol S. Bebeklik dönemindeki bağlanma sürecine genel bir bakış. Klinik Psikiyatri 2005;8:8899.

10. Öztürk S, Erci B. Postpartum dönemdeki primipar annelere loğusa ve yenidoğan bakım eğitimi maternal bağlanmayı arttırdı: son test kontrol gruplu eğitimsel araştırma. Balıkesir Sağlık Bilimleri Dergisi 2016;5:129-34.

11. Güleşen A, Yıldız D. Erken postpartum dönemde anne bebek bağlanmasının kanıta dayalı uygulamalar ile incelenmesi. TSK Koruyucu Hekimlik Bülteni 2013;12:177-82.

12. Britton JR, Britton HL, Gronwaldt V. Breastfeeding, sensitivity, and attachment. Pediatrics 2006;118:e1436-43.

13. World Health Organization. Maternal mental health. 2015. Retrieved from: http://www.who.int/mental_health/maternalchild/maternal_mental_health/en/

14. Kavlak O, Sirin A. The Turkish version of maternal attachment inventory. Uluslararası İnsan Bilimleri Dergisi 2009;6: 188-202.

15. Mutlu C, Yorbık Ö, Tanju İA, Çelikel F, Sezer R.G. Doğum öncesi, doğum sırası ve doğum sonrası etkenlerin annenin bağlanması ile ilişkisi. Anadolu Psikiyatri Dergisi 2015;16:442_ 50.

16. Çankaya S, Yilmaz SD, Can R, Kodaz ND. Postpartum depresyonun maternal bağlanma üzerine etkisi. Acıbadem Üniversitesi Sağlık Bilimleri Dergisi 2017;8:232-40.

17. Durualp E, Kaytez N, Girgin BA. Evlilik doyumu ve maternal bağlanma arasındaki ilişkinin incelenmesi. Anadolu Psikiyatri Dergisi 2017;18:129-38.

18. Niemann S, Weiss S. Factors affecting attachment in international adoptees at 6 months post adoption. Child Youth Serv Rev 2012;34:205-12.

19. Kırca AŞ, Savaşer S. Doğum sayısının anne bebek bağlanmasına etkisi. Sağlık Bilimleri ve Meslekleri Dergisi 2017;4:236-43. 
20. Provenzi L, Broso S, Montirosso R. Do mothers sound good? A systematic review of the effects of maternal voice exposure on preterm infants' development. Neurosci Biobehav Rev 2018; $88: 42-50$.

21. Fernández Medina IM, Granero-Molina J, Fernández-Sola C Hernández-Padilla JM, Camacho Ávila M, López Rodriguez MDM. Bonding in neonatal intensive care units: experiences of extremely preterm infants' mothers. Women Birth 2018;31: 325-30.
22. Ohoka H, Koide T, Goto S, Murase S, Kanai A, Masuda T, et al. Effects of maternal depressive symptomatology during pregnancy and the postpartum period on infant-mother attachment. Psychiatry Clin Neurosci 2014;68:631-9.

23. Petri E, Palagini L, Bacci O, Borri C, Teristi V, Corezzi C, et al. Maternal-foetal attachment independently predicts the quality of maternal-infant bonding and post-partum psychopathology. J Matern Fetal Neonatal Med 2017;21:17. 